\title{
Chemical Fingerprinting of the Geranium (Pelargonium graveolens) Essential Oil by Using FTIR, Raman and GC-MS Techniques
}

\author{
Nur Cebi ${ }^{1}$ \\ $1^{*}$ Yıldız Technical University, Chemical and Metallurgical Engineering Faculty, Food Engineering Department, İstanbul, Turkey, (ORCID: 0000-0002-5509-0985), \\ nurcebi@yildiz.edu.tr
}

(First received 11 June 2021 and in final form 28 August 2021)

(DOI: $10.31590 /$ ejosat.969661)

ATIF/REFERENCE: Çebi, N. (2021). Chemical Fingerprinting of the Geranium (Pelargonium graveolens) Essential Oil by Using FTIR, Raman and GC-MS Techniques. European Journal of Science and Technology, (25), 810-814.

\begin{abstract}
Geranium oil is known as a floral substitute for rose essential oil with its pungent rose-like odor and is one of the most valuable essential oils. Favorable quality properties make the geranium essential oil exigible for food industry applications. This study determined the chemical fingerprint of geranium essential oil using robust vibrational spectroscopy techniques (Fourier transform infrared spectroscopy and Raman spectroscopy). The mid-infrared characterization was accomplished on the basis of functional chemical groups of geranium essential oil. GC-MS (gas chromatography-mass spectroscopy) technique was used for the detection and quantification of the volatile constituents of geranium essential oil. 37 (thirty-seven) volatile compounds were determined by the GCMS analysis. The most abundant compounds were determined as citronellol (30.68\%), geraniol (9.68\%) and citronelly formate $(9.90 \%)$.
\end{abstract}

Keywords: Geranium essential oil, FTIR, Raman, GC-MS

\section{Itır (Pelargonium graveolens) Uçucu Yağının FTIR, Raman ve GC-MS Teknikleri Kullanılarak Kimyasal Parmak İzinin Tespit Edilmesi}

$\ddot{\mathbf{O z}}$

Itır uçucu yağı, keskin gül benzeri kokusu ile gül esansiyel yağının bir çeşit ikamesi olarak bilinir ve en değerli esansiyel yağlardan biridir. Eşsiz kalite özellikleri, ıtır esansiyel yağını gıda endüstrisi uygulamaları için çekici kılmaktadır. Bu çalışma, güçlü titreşim spektroskopisi teknikleri (Fourier dönüşümlü kızılötesi spektroskopisi ve Raman spektroskopisi) kullanarak ıtır esansiyel yağının kimyasal parmak izini belirlemiştir. FTIR ve Raman karakterizasyonları, ıtır esansiyel yağının fonksiyonel kimyasal grupları temelinde gerçekleştirilmiştir. Itır uçucu yağının uçucu bileşenlerinin tespiti ve miktarının belirlenmesi için GC-MS (gaz kromatografisi-kütle spektroskopu) tekniği kullanılmıştır. 37 (otuz yedi) uçucu bileşen GC-MS analizi ile belirlenmiştir. Relatif olarak en bol miktarda bulunan bileşikler sitronellol (\%30.68), geraniol (\%9.68) ve sitronelil format (\%9.90) olarak belirlenmiştir.

Anahtar Kelimeler: Itır uçucu yağı, FTIR, Raman, GC-MS, kimyasal parmak izi

* Corresponding Author: nurcebi@yildiz.edu.tr 


\section{Introduction}

Essential oils are "golden" natural extracts with high commercial worth and wide usage area. In recent years, natural products, natural extracts and non-synthetic materials gained importance (Boukhatem et al., 2013). Especially essential oils with their wide application area, health beneficial properties and industrial importance came into prominence. Essential oils are desired by flavor, fragrances, cosmetics, aromatherapy, and phytomedicine industries oils due to their functional and unique chemical structures and properties (Cebi et al., 2021a).

Geranium (Pelargoniumg graveolens) belongs to Geraniaceae family and it is widely cultivated in Reunion Island, Madagascar, Egypt (North African-type) and China, and more recently in India (Gomes et al., 2004). Geranium oil has been known as a floral substitute of rose essential oil with its pungent rose-like odor and is one of the most valuable essential oils (Rezaei Nejad and Ismaili, 2014). Previous studies reported that rose-scented geranium essential oil is widely used in cosmetic and food flavor industries. Other beneficial properties of geranium essential oil can be listed as antibacterial, antifungal, anti-inflammatory, spasmolytic, antidiabetic and hypoglycemic effects. Additionally, geranium essential oil is generally recognized as safe (GRAS) and approved by the American Food and Drug Administration (FDA) (Boukhatem et al., 2013). Due to the industrial importance and significant quality properties, various studies were published for investigation of the chemistry and constituents of the geranium essential oil using robust instrumental analysis techniques. Guerrini et al. (2011) utilized gas chromatography-mass spectrometry (GC-MS) and nuclear magnetic resonance (NMR) techniques for chemical fingerprinting of the South-African Pelargonium capitatum (Geraniaceae) essential oil (Guerrini et al., 2011). Afifi et al. (2014) used GC-MS solid phase microextraction method to evaluate chemical composition of the pelargonium essential oil and the activity of the essential oil against pancreatic triacylglycerol lipase, $\alpha$ - amylase and $\alpha$-glucosidase. In another study, Dyubeni et al. used GC-MS (gas chromatography-mass spectroscopy) technique to determine the chemical composition and main volatile compounds of rose-scented geranium (Dyubeni et al., 2012). The gas chromatography mass spectroscopy (GC-MS) technique especially could be regarded as the gold standard since the combination of gas chromatography with mass spectroscopy provides opportunities for the identification of unknown components with high accuracy (Tulukcu et al., 2019). As powerful techniques, FTIR (Fourier transform infrared) and Raman spectroscopy techniques can be utilized for the determination of the chemical fingerprint of geranium essential oil. Vibrational spectroscopy techniques such as FTIR and Raman has been reported as fast, easy to operate, accurate, strong, and economical analytical techniques that provide specific fingerprint information about the chemical structure of materials (Cebi et al., 2021b)

Essential oils are high-valued natural extracts with high commercial worth and wide usage area. In recent years, natural products, natural extracts and non-synthetic materials gained importance. The current research is built for the identification of the chemical fingerprint of geranium essential oil by using GCMS, FTIR and Raman techniques. To the best of our knowledge, this study is the first attempt that used three different analytical techniques for the chemical fingerprinting of the precious Geranium (Pelargonium graveolens) essential oil.

\section{Material and Method}

\subsection{Equipment}

A Rigaku Progeny X2 spectrometer (Rigaku Raman Technologies, Wilmington, DE, USA) was used for Raman measurements at the spectral range of 200 and $2000 \mathrm{~cm}^{-1}$. FTIR spectra were collected using single-bounce FTIR spectra coupled with ATR (attenuated total reflectance) accessory. Total ion chromatogram was obtained by using GCMS-QP2010 gas chromatography-mass spectrometer system (Shimadzu, Milan, Italy). Volatile compounds and their relative abundance was determined by comparison of the GC-MS data with the commercial libraries of NIST27 and WILEY7.

\subsection{Material}

The geranium (Pelargonium graveolens) essential oil was obtained from a reliable essential oil producer. The steam distilled Pelargonium graveolens (leaves and tops) was certified as $100 \%$ pure and natural by the legal regulations. The appearance, odor, refractive index, specific gravity, optical rotation and solubility values were reported as "pale yellow to light greenish-yellow colored liquid", "very fresh, lightly floral, lemony-rosy aroma", "1.465", "0.889”, " $-18^{\circ}$ to $-7^{\circ}$ ", "soluble in alcohols and fixed oils; insoluble in water", respectively. Additionally, odor quality was reported as excellent. The geographical origin of the geranium (Pelargonium graveolens) was Egypt.

\subsection{Raman Spectral Acquisition}

Raman spectral acquisition was performed at room temperature. Standardization and calibration of the Rigaku Raman spectrometer was performed using a benzonitrile standard solution prior to the measurements. Spectra were collected through Raman vials. Measurement parameters of laser, laser power and exposure time were determined as $1064 \mathrm{~nm}$ YAG laser, $0.25 \mathrm{~W}$ and $0.851 \mathrm{~s}$, respectively. The spectral acquisition was performed for five times and an average spectrum was obtained.

\subsection{FTIR Spectral Acquisition}

FTIR measurements were performed at room temperature. Samples were placed on the diamond crystal of ATR accessory (single-bounce) by using a pipette at the constant volume of 20 $\mu 1$. The spectral acquisition was performed with the resolution and accumulation values of $4 \mathrm{~cm}^{-1}$ and 16 scans, respectively. Instrument control and data acquisition was performed by the software of FTIR spectrometer (OPUS program Version 7.2 (Bruker Gmbh). All measurements were scanned against the background air spectrum.

\subsection{GC-MS Analysis}

GC-MS analyses were performed according to the previous publications (Cebi et al., 2021b) with slight modifications. Restec 5MS fused silica capillary column $(30 \mathrm{~m} \times 0.25 \mathrm{~mm} \times$ $0.25 \mu \mathrm{m}$ ) was used for chromatographic separation. Oven temperature was adjusted as: $40{ }^{\circ} \mathrm{C}$ for $3 \mathrm{~min}, 100{ }^{\circ} \mathrm{C}(8$ $\left.{ }^{\circ} \mathrm{C} / \mathrm{min}\right), 200{ }^{\circ} \mathrm{C}\left(5^{\circ} \mathrm{C} / \mathrm{min}\right), 250{ }^{\circ} \mathrm{C}\left(10{ }^{\circ} \mathrm{C} / \mathrm{min}\right), 250{ }^{\circ} \mathrm{C}(10$ $\mathrm{min})$. The flow rate of the $\mathrm{He}$ gas was adjusted as $1 \mathrm{~mL} / \mathrm{min}$. 
Diethyl ether diluted samples $(1: 10)$ were injected to the system at the injection volume of two $\mu \mathrm{L}$ (split ratio of $1 / 10$ ). The mass scan was performed at the mass range of 35 to $650(\mathrm{~m} / \mathrm{z})$. Identification and quantification of volatile constituents was accomplished by comparison of using the total-ion chromatogram with the commercial libraries (NIST27 and WILEY7)of the GC-MS system. The quantity of each detected constituent was calculated on the basis of relative abundance.

\section{Results and Discussion}

\subsection{Interpretation of the FTIR spectrum of geranium (Pelargonium graveolens) essential oil}

FTIR spectrum of the Geranium (Pelargonium graveolens) is presented in Figure 1. As it can be seen from the Figure 1, significant bands were observed at 3354, 2961, 2916, 2871, $1728,1713,1451,1377,1173,1057,1008,831$ and $737 \mathrm{~cm}^{-1}$. The peak at $3354 \mathrm{~cm}^{-1}$ may be due to the $\mathrm{O}-\mathrm{H}$ stretching vibrations of alcohols in the composition of geranium oil. The peak at $2961 \mathrm{~cm}^{-1}$ is resulted from the $\mathrm{C}=\mathrm{C}-\mathrm{C}$ ring vibrations of volatile compounds (Cebi et al., 2021b). The significant bands at $2916 \mathrm{~cm}^{-1}$ and $2871 \mathrm{~cm}^{-1}$ may be attributed to the $-\mathrm{C}-\mathrm{H},-\mathrm{CH}_{2}$ asymmetric stretching and $-\mathrm{C}-\mathrm{H},-\mathrm{CH}$ symmetric stretching vibrations, respectively (Taylan et al., 2021). The bands at 1728 and $1713 \mathrm{~cm}^{-1}$ may be assigned to the carbonyl $(\mathrm{C}=\mathrm{O})$ stretching vibrations (Agatonovic-Kustrin et al., 2020). The sharp peaks at 1451 and $1377 \mathrm{~cm}^{-1}$ may correspond to the $\mathrm{CH}_{2}$ deformation and asymmetrical $\mathrm{CH}_{3}$ deformation vibrations (Agatonovic-Kustrin et al., 2020). The sharp band at 1173 may be assigned to the C-O stretching vibrations (Berechet et al., 2015). The bands at 1008 and $831 \mathrm{~cm}^{-1}$ may correspond to the methylene vibrations and $\mathrm{C}$ $\mathrm{H}$ out-of-plane bending vibrations, respectively (AgatonovicKustrin et al., 2020\& Cebi et al., 2021b ).

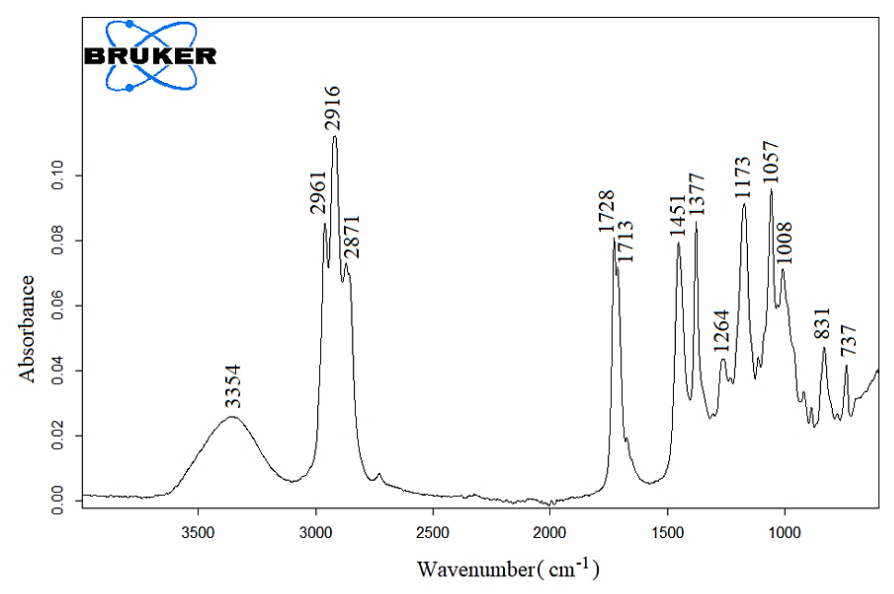

Figure 1. ATR-FTIR spectrum of Geranium (Pelargonium Graveolens) essential oil at the spectral range of $4000-600 \mathrm{~cm}^{-1}$.

\subsection{Interpretation of the Raman spectrum of Geranium (Pelargonium graveolens) essential oil}

The Raman spectrum of the Geranium (Pelargonium graveolens) essential oil is presented in Figure 2 at the spectral range of $2000-200 \mathrm{~cm}^{-1}$. One can clearly see that significant bands are observed at 1670, 1455, 1385, 1346, 1301, 1108, $1007,800,450$ and $301 \mathrm{~cm}^{-1}$. The sharpest bands at $1670 \mathrm{~cm}^{-1}$ and $1455 \mathrm{~cm}^{-1}$ correspond to the $\mathrm{C}=\mathrm{C}$ stretching vibrations and $\mathrm{CH}_{3} / \mathrm{CH}_{2}$ bending vibrations, respectively (Jentzsch et al., 2015). The narrow and sharp Raman band at $1385 \mathrm{~cm}^{-1}$ is due to the $\mathrm{CH}_{3}$ bending (attached to a $\mathrm{C}=\mathrm{C}$ ) vibrations (Cebi et al., 2021b). Two bands at 1346 and $1301 \mathrm{~cm}^{-1}$ may be assigned to the $\mathrm{CH}_{3}$ bending (attached to a $\mathrm{C}=\mathrm{C}$ ) vibrations and $=\mathrm{CH}$ rocking vibrations, respectively (Jentzsch et al., 2015). The widest bands with low intensity at 1007 and $800 \mathrm{~cm}^{-1}$ may be assigned to the $\mathrm{CH}$ bending vibrations and $\mathrm{C}-\mathrm{O}$ stretching (alcohol) vibrations, respectively (Cebi et al., 2021b).

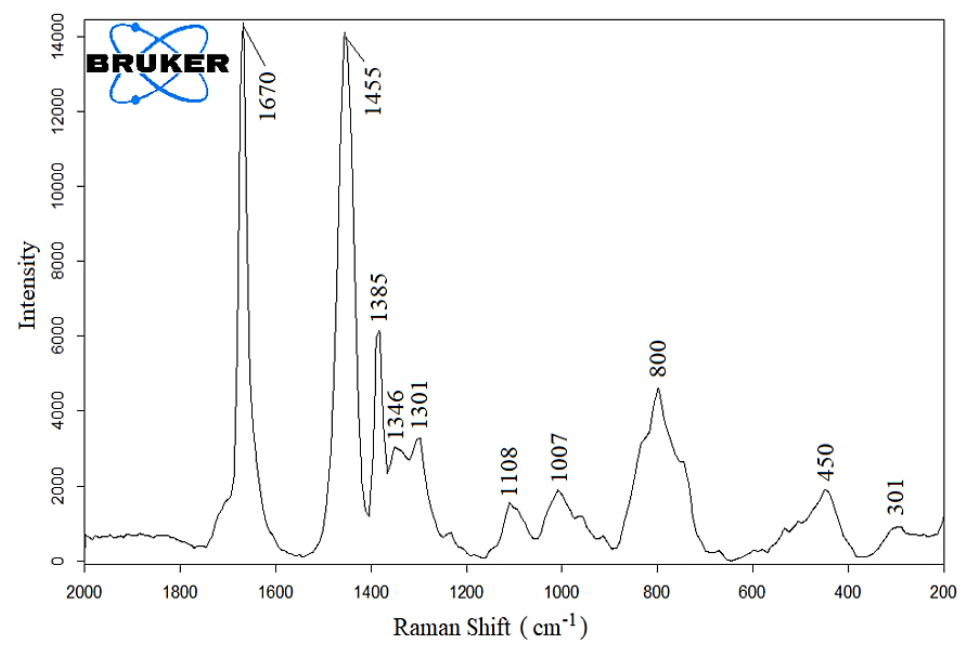

Figure 2. Raman spectrum of Geranium (Pelargonium graveolens) essential oil at the spectral range of $2000-200 \mathrm{~cm}^{-1}$.

\subsection{Volatile Compound Composition of Geranium (Pelargonium graveolens) essential oil}

Volatile compounds of the Geranium (Pelargonium graveolens) essential oil were determined by using GC-MS technique. The relative percentages of the detected compounds are presented in Table 1. The relative quantity of each constituent was determined by comparison of the GC-MS data with the commercial databases (NIST 27 and WILEY 7) of GC-MS system. The identification of these compounds were performed by comparison of the total ion chromatogram with the commercial libraries (NIST27 and WILEY7) of the GC-MS instrument. 37 (thirty-seven) volatile compounds were determined by the GC-MS analysis. Detected volatile compounds of the Geranium (Pelargonium graveolens) essential oil represented the $99.34 \%$ of whole essential oil composition. The relative content (\%) of each volatile compound of the geranium essential oil was calculated on the basis of the peak area. 
Table 1. Composition (\%), retention time (R.T.) and volatile compounds in Geranium (Pelargonium graveolens) essential oil

\begin{tabular}{|c|c|c|}
\hline Content (\%) & Chemical Name & R.T $\mathbf{T}^{\mathrm{a}}$ \\
\hline $0.11 \pm 0.02$ & $\beta$-Myrcene & 9.99 \\
\hline $0.12 \pm 0.03$ & $\beta$-Ocimene & 11.32 \\
\hline $0.18 \pm 0.04$ & Linalool oxide cis & 12.00 \\
\hline $4.23 \pm 0.05$ & Linalool & 12.91 \\
\hline $3.86 \pm 0.07$ & Rose oxide B & 13.17 \\
\hline $0.1 \pm 0.06$ & Isopulegol & 14.23 \\
\hline $2.18 \pm 0.03$ & p-Menthone & 14.49 \\
\hline $5.2 \pm 0.01$ & L-menthal one & 14.87 \\
\hline $0.97 \pm 0.15$ & p- Menth-1-en-8-ol & 15.6 \\
\hline $0.94 \pm 0.06$ & $\alpha-$ Citronellol & 16.43 \\
\hline $30.68 \pm 0.09$ & Citronellol & 17.11 \\
\hline $9.68 \pm 0.02$ & Geraniol & 17.76 \\
\hline $9.90 \pm 0.44$ & Citronellyl formate & 18.15 \\
\hline $2.72 \pm 0.02$ & Geraniol formate & 18.80 \\
\hline $0.56 \pm 0.12$ & Oxiranemethanol & 19.74 \\
\hline $1.07 \pm 0.25$ & 6-Octen-1-ol & 20.14 \\
\hline $0.2 \pm 0.05$ & 1,7-Octanediol & 20.41 \\
\hline $1.86 \pm 0.02$ & 2,6-Octadien-1-ol & 20.98 \\
\hline $0.24 \pm 0.03$ & 2,6,10-Dodecatrien-1-ol & 21.30 \\
\hline $2.32 \pm 0.02$ & $\alpha$-Gurjunene & 21.83 \\
\hline $1.66 \pm 0.36$ & Caryophyllene & 22.12 \\
\hline $3.21 \pm 0.05$ & Citronellyl propionate & 22.54 \\
\hline $0.1 \pm 0.08$ & Neryl acetate & 22.77 \\
\hline $0.62 \pm 0.02$ & $\alpha$-Humulene & 22.97 \\
\hline $1.75 \pm 0.01$ & Geranyl propionate & 23.32 \\
\hline $0.37 \pm 0.07$ & Azulene & 23.42 \\
\hline $0.22 \pm 0.06$ & $\beta$-Selinene & 23.82 \\
\hline $0.34 \pm 0.03$ & $\alpha$-Selinene & 24.01 \\
\hline $0.15 \pm 0.17$ & Ledol & 24.24 \\
\hline $3.47 \pm 0.28$ & Citronellyl butyrate & 24.68 \\
\hline $2.44 \pm 0.08$ & Geranyl butyrate & 25.45 \\
\hline $2.6 \pm 0.38$ & Phenylethyl tiglate 2 & 26.14 \\
\hline $0.2 \pm 0.09$ & Caryophyllene oxide & 26.82 \\
\hline $0.16 \pm 0.16$ & 2-Dodecenal & 27.09 \\
\hline $2.1 \pm 0.05$ & Citronellyl propionate & 27.94 \\
\hline $2.76 \pm 0.64$ & Geranyl tiglate & 28.73 \\
\hline $0.07 \pm 0.05$ & Thiogeraniol & 33.60 \\
\hline 99.34 & & \\
\hline
\end{tabular}

\section{Discussion and Conclusions}

Geranium (Pelargonium graveolens) essential oil has considerable economic and industrial importance. Favorable flavor of geranium essential oil and health-beneficial properties such as antibacterial, antifungal, anti-inflammatory, spasmolytic and antidiabetic effects makes the geranium essential oil appealing for food industry applications. This research e-ISSN: 2148-2683 investigated the chemical fingerprinting properties of geranium essential oil using vibrational spectroscopy and gas chromatography mass-spectrometry. Quite limited studies were performed to reveal chemical characterization of geranium essential oil. To the best of our knowledge, only one study made contributions about the FTIR characterization of geranium essential oil, Bounass et al. (2018) studied the counterfeit identification of essential oils through middle infrared study, in this valuable study, they general characterized the ATR-FTIR spectra of commercial essential oils (Bounaas et al., 2018). In the scope of this current study, specific vibrational spectroscopy (FTIR \& Raman) characterization was performed for geranium essential oil. The functional chemical groups which are specific to the geranium essential oil were determined by FTIR and Raman techniques. Spectra from the MIR region are commonly used for structural identification (fingerprinting) of organic compounds because the absorption bands are caused by fundamental vibrations of a specific functional group (Rodriguez-Saona and Allendorf, 2011). Although quite limited studies were reported about the characterization of the geranium essential oil, lots of valuable studies were reported that proved the capability and effectiveness of vibrational spectroscopy (FTIR\&Raman) for quality evaluation of various essential oils (Bounaas et al., 2018; Cebi et al., 2021b; Do et al., 2015; Taylan et al., 2021).

Additionally, GC-MS technique was used for detection and quantification of the volatile constituents of geranium essential oil. The most abundant compounds were determined as citronellol (30.68\%), geraniol (9.68\%) and citronelly formate $(9.90 \%)$. Several studies were dedicated for the determination of the volatile compounds in the compositon of the geranium (Pelargonium graveolens) essential oil using GC-MS technique. Consistently with our results, Mnif et al. (2013) determined the most abundant volatile compounds as citronellol $(27.53 \%)$ and geraniol $(25.85 \%)$ in Pelargonium graveolens leaves essential oil (Mnif et al., 2011). In the current research, citronellol content was determined as $30.68 \%$, similarly, Boukhatem et al. (2013) showed that rose-scented geranium essential oil (Algeria) had $30.2 \%$ citronellol content (Boukhatem et al., 2013). They also detected citronellyl formate at the concentration of $9.3 \%$. In our study, citronellyl formate was determined at the concentration of $9.90 \%$. Additionally, while the geraniol content was reported as $7.6 \%$ in their study, it was determined as $9.68 \%$ in the current research. In another research, citronellol content and p-menthone content were reported as $48.44 \%$ and $6.96 \%$, respectively (Mousavi et al., 2014). In the current research, p-menthone content was quantified as $2.18 \%$. Jalali-Heravi (2006) presented the essential oil components of Iranian geranium oil using GCMS analysis. They reported the linalool, trans-Rose oxide, 1menthone, beta-citronellol, geraniol and citronellyl formate contents as $3.07 \%, 1.72 \%, 2.1 \%, 47.46 \%, 8.74 \%$ and $11.00 \%$, respectively (Jalali-Heravi et al., 2006). In the present research, linalool, Rose oxide B, p-menthone, citronellol, geraniol and citronellyl formate contents were determined as $4.23 \%, 3.86 \%$, $2.18 \%, 30.68 \%, 9.68 \%$ and $9.90 \%$, respectively. In general quite compatible volatile compound results were observed but little differences may be observed because of the climatic and geographic factors.

As conclusion, this study presented the FTIR and Raman chemical fingerprint of geranium essential oil. FTIR and Raman results showed the functional chemical groups which are unique for the geranium essential oil. GC-MS results revealed the 813 
volatile compound composition of geranium essential oil using the superiorities of the mass detector. Major volatile compounds were determined as citronellol, geraniol and citronellyl formate. Chemical characterization of geranium essential oil will shed light to the researchers and industrial applicators to develop new commercial products in the sectors such as cosmetics, food and beverage, alternative medicine, aromatherapy and cleaning and home.

\section{References}

Agatonovic-Kustrin, S., Ristivojevic, P., Gegechkori, V., Litvinova, T.M., and W. Morton, D. (2020). Essential oil quality and purity evaluation via FT-IR Spectroscopy and pattern recognition techniques. Appl. Sci., 10, 7294.

Berechet, M.D., Calinescu, I., Stelescu, M.D., Manaila, E., Craciun, G., Purcareanu, B., Mihaiescu, D.E., Rosca, S., Fudulu, A., Niculescu-Aron, I.G., et al. (2015). Composition of the essential oil of Rosa damascena Mill. cultivated in Romania. Rev. Chim., 66, 1986-1991.

Boukhatem, M.N., Kameli, A., and Saidi, F. (2013). Essential oil of Algerian rose-scented geranium (Pelargonium graveolens): Chemical composition and antimicrobial activity against food spoilage pathogens., Food Control, 34, 208-213.

Bounaas, K., Bouzidi, N., Daghbouche, Y., Garrigues, S., de la Guardia, M., and El Hattab, M. (2018). Essential oil counterfeit identification through middle infrared spectroscopy. Microchem. J., 139, 347-356.

Cebi, N., Taylan, O., Abusurrah, M., and Sagdic, O. (2021a). Detection of orange essential oil, isopropyl myristate, and benzyl alcohol in lemon essential oil by FTIR spectroscopy combined with chemometrics. Foods., 10, 27

Cebi, N., Arici, M., and Sagdic, O. (2021b). The famous Turkish rose essential oil: Characterization and authenticity monitoring by FTIR, Raman and GC-MS techniques combined with chemometrics. Food Chem., 354, 129495.

Do, T.K.T., Hadji-Minaglou, F., Antoniotti, S., and Fernandez, X. (2015). Authenticity of essential oils. TrAC - Trends Anal. Chem., 66, 146-157.

Dyubeni, L., Mayekiso, B., and Magwa, M.. (2012). A comparative study on essential oil yield and composition of rose-scented geranium commercially grown on three different sites of the Amathole region in the Eastern Cape, South Africa. African J. Agric. Res., 7, 5842-5848.

Gomes, P.B., Mata, V.G., and Rodrigues, A.E. (2004). Characterization of Portuguese-grown geranium oil (pelargonium sp.). J. Essent. Oil Res., 16, 490-495.

Guerrini, A., Rossi, D., Paganetto, G., Tognolini, M., Muzzoli, M., Romagnoli, C., Antognoni, F., Vertuani, S., Medici, A., Bruni, A., et al. (2011). Chemical characterization (GC/MS and NMR fingerprinting) and bioactivities of South-African pelargonium capitatum (L.) L'her. (Geraniaceae) essential oil. Chem. Biodivers., 8, 624-642.

Jalali-Heravi, M., Zekavat, B., and Sereshti, H. (2006). Characterization of essential oil components of Iranian geranium oil using gas chromatography-mass spectrometry combined with chemometric resolution techniques. $J$. Chromatogr., A 1114, 154-163.

Jentzsch, P., Ramos, L., and Ciobotă, V. (2015). Handheld Raman spectroscopy for the distinction of essential oils used in the cosmetics industry. Cosmetics., 2, 162-176.

Mnif, W., Dhifi, W., Jelali, N., Baaziz, H., Hadded, A., and
Hamdi, N. (2011). Characterization of leaves essential oil of pelargonium graveolens originating from Tunisia: Chemical composition, antioxidant and biological activities. J. Essent. Oil-Bearing Plants., 14, 761-769.

Mousavi, E.S., Dehghanzadeh, H., and Abdali, A. (2014). Chemical composition and essential oils of Pelargonium graveolens (Geraniaceae) By Gas Chromatography - Mass Spectrometry (GC/MS). Bull. Env. Pharmacol. Life Sci., 3, 182-184.

Rezaei Nejad, A., and Ismaili, A. (2014). Changes in growth, essential oil yield and composition of geranium (Pelargonium graveolens L.) as affected by growing media. J. Sci. Food Agric., 94, 905-910.

Rodriguez-Saona, L.E., and Allendorf, M.E. (2011). Use of FTIR for rapid authentication and detection of adulteration of food. Annu. Rev. Food Sci. Technol., 2, 467-483.

Sandasi, M., Kamatou, G.P.P., Gavaghan, C., Baranska, M., and Viljoen, A.M. (2011). A quality control method for geranium oil based on vibrational spectroscopy and chemometric data analysis. Vib. Spectrosc., 57, 242-247.

Taylan, O., Cebi, N., and Sagdic, O. (2021). Rapid screening of mentha spicata essential oil and 1-menthol in mentha piperita essential oil by ATR-FTIR spectroscopy coupled with multivariate analyses. Foods, 10, 202

Tulukcu, E., Cebi, N., Sagdic, O. (2019). Chemical fingerprinting of seeds of some salvia species in Turkey by using GC-MS and FTIR. Foods, 8, 1-12. 